\title{
Brain Immune Interactions-Novel Emerging Options to Treat Acute Ischemic Brain Injury
}

\author{
Sajjad Muhammad ${ }^{1,2,3, * \mathbb{C}}$, Shafqat Rasul Chaudhry ${ }^{3,4}$, Ulf Dietrich Kahlert ${ }^{1}{ }^{\mathbb{D}}$, Mika Niemelä ${ }^{2}$ \\ and Daniel Hänggi ${ }^{1}$ \\ 1 Department of Neurosurgery, Faculty of Medicine and University Hospital Düsseldorf, \\ Heinrich-Heine University Düsseldorf, Moorenstrasse 5, D-40225 Düsseldorf, Germany; \\ ulf.kahlert@med.uni-duesseldorf.de (U.D.K.); daniel.haenggi@med.uni-duesseldorf.de (D.H.) \\ 2 Department of Neurosurgery, University of Helsinki and Helsinki University Hospital, \\ 00100 Helsinki, Finland; mika.niemela@hus.fi \\ 3 Department of Neurosurgery, University Hospital Bonn, D-53127 Bonn, Germany; shafqatrasul@yahoo.com \\ 4 College of Pharmaceutical Sciences, Shifa Tameer-e-Millat University, Islamabad 44000, Pakistan \\ * Correspondence: sajjad.muhammad@med.uni-duesseldorf.de; Tel.: +49-15168460755
}

check for updates

Citation: Muhammad, S.; Chaudhry, S.R.; Kahlert, U.D.; Niemelä, M.;

Hänggi, D. Brain Immune

Interactions-Novel Emerging

Options to Treat Acute Ischemic Brain Injury. Cells 2021, 10, 2429. https://

doi.org/10.3390/cells10092429

Academic Editors: Antonio

Rodríguez-Sinovas, Javier Inserte and Marisol Ruiz-Meana

\section{Received: 8 July 2021}

Accepted: 13 September 2021

Published: 15 September 2021

Publisher's Note: MDPI stays neutral with regard to jurisdictional claims in published maps and institutional affiliations.

Copyright: (c) 2021 by the authors. Licensee MDPI, Basel, Switzerland. This article is an open access article distributed under the terms and conditions of the Creative Commons Attribution (CC BY) license (https:/ / creativecommons.org/licenses/by/ $4.0 /)$.

\begin{abstract}
Ischemic stroke is still among the leading causes of mortality and morbidity worldwide. Despite intensive advancements in medical sciences, the clinical options to treat ischemic stroke are limited to thrombectomy and thrombolysis using tissue plasminogen activator within a narrow time window after stroke. Current state of the art knowledge reveals the critical role of local and systemic inflammation after stroke that can be triggered by interactions taking place at the brain and immune system interface. Here, we discuss different cellular and molecular mechanisms through which brain-immune interactions can take place. Moreover, we discuss the evidence how the brain influence immune system through the release of brain derived antigens, damage-associated molecular patterns (DAMPs), cytokines, chemokines, upregulated adhesion molecules, through infiltration, activation and polarization of immune cells in the CNS. Furthermore, the emerging concept of stemness-induced cellular immunity in the context of neurodevelopment and brain disease, focusing on ischemic implications, is discussed. Finally, we discuss current evidence on brain-immune system interaction through the autonomic nervous system after ischemic stroke. All of these mechanisms represent potential pharmacological targets and promising future research directions for clinically relevant discoveries.
\end{abstract}

Keywords: ischemic stroke; inflammation; immune cells; neuroimmune axis; stem cell

\section{Introduction \\ 1.1. Epidemiology and Pathophysiology of Stroke}

Stroke is the third leading cause of death following heart diseases and cancer. Stroke affects around 15 million people yearly worldwide [1]. The majority of the strokes are ischemic [2], but still approximately two million cases are the hemorrhagic type of stroke [3]. Moreover, stroke is the leading cause of long-term disability worldwide and poses a profound economic burden [1]. Despite years of intensive research, therapeutic options are still limited to recanalization strategies either by thrombectomy utilizing stent retrievers $[4,5]$ or thrombolysis with recombinant tissue plasminogen activator (rtPA) with a limited time window up to $4.5 \mathrm{~h}$ [6]. Both therapeutic options have their limitations and can lead to life threatening intracranial bleeding. All efforts to search for an effective neuroprotective drug for cerebral ischemia have proved futile. Due to limitations of therapeutic options in clinical practice, there is an urgent need to explore and identify new treatment targets located within and outside the brain. 


\subsection{Inflammation and Immune Response after Cerebral Ischemia}

Ample evidence suggests that local and systemic inflammation plays a pivotal role in cerebral ischemia [2,7-15]. The pathophysiology of cerebral ischemia is, however, complex. Reduction of blood supply to the brain initiates the ischemic cascade that leads to neuronal death and rapid loss of neuronal function [2]. This ischemic cascade is characterized by the activation of several cellular signaling pathways that compromise cell survival and function [16]. Furthermore, ischemic stroke triggers blood-brain barrier (BBB) disruption, thus contributing to the secondary progression of ischemic injury by increasing brain edema and exacerbating the inflammatory response in the subacute phase [2,17]. The severity of these early events influences the capacity of neurons to recover in the chronic phase.

The injury of nervous tissue leads to release of neuronal antigens, ATP and damageassociated molecular patterns (DAMPs) that elicit activation of immune response. Moreover, the release of chemokines and cytokines released from the injured brain can also activate the immune system and increased expression of adhesion molecules facilitates immune cell infiltration. Furthermore, the autonomic nervous system releases acetylcholine and norepinephrine, which can also regulate the immune system. The dynamics of activation of different immunological players after stroke varies. The innate immune system initiates an early response against brain injury. The cells of innate immunity within the brain (microglia) sense the brain injury through pattern recognition receptors including TLRs and NOD-like receptors (NLRs) [18] leading to activation of downstream pathways such as NF- $\mathrm{kB}$ and MAPK pathways resulting in production of proinflammatory cytokines, chemokines and reactive oxygen species (ROS). Similarly, bone-marrow-derived innate immune cells including macrophages, neutrophils, dendritic and natural killer cells infiltrate into the brain through disrupted blood-brain barrier and initiate an acute, nonspecific and quick response that is relatively similar to the intrinsic innate immune response [18]. On the other hand, infiltrated cells of the adaptive immune system, such as T cells, initiate a delayed, but specific response that plays a key role during repair and remodeling [18]. Coordinated crosstalk between the injured brain and peripheral immune system is important to determine the clinical outcome.

\section{Means of Interaction between Brain and Immune Cells}

After cerebral injury, the brain and immune system influence each other through multiple mechanisms and in a very specific way. This bidirectional neuroimmune communication might be important to regulate repair, regeneration and vascular remodeling [19]. How the brain activates the immune system and through which molecules brain-immune interactions take place is an emerging frontier and is under intensive investigations. There is now an ample evidence that both the injured brain and the immune system communicate with each other to reestablish the homeostasis [20]. There are multiple ways to facilitate this communication, including brain-derived antigens, danger-associated molecular patterns (DAMPs), immune signaling molecules and signals via sympathetic and parasympathetic nervous system.

\subsection{Activation of Immune System through Brain Derived Antigens}

A tight blood-brain barrier (BBB) warrants brain to be relatively immune privileged compared to peripheral organs. However, accumulating data have shown that in different pathological conditions, disrupted BBB facilitates a bidirectional communication between brain and immune cells. Brain derived antigens released via disrupted BBB into systemic circulation encounter immune cells and initiate immune response. A prominent example for such a communication is multiple sclerosis, where the immune system is exposed to myelin antigens [21] resulting in infiltration of antigen specific T-cells in the brain that cause demyelination [22]. Disrupted BBB during stroke allows antigens to enter from the brain into the systemic circulation and interact with immune cells. The studies in human stroke exhibit increased titers of antibodies against neurofilaments and N-methyl-D-aspartic acid (NMDA) receptor, showing the previous contact with these antigens [23,24]. Furthermore, 
microtubule-associated protein 2 (MAP2), NMDA receptor subunit NR-2A, myelin basic protein (MBP) and myelin oligodendrocyte glycoprotein [25] were found in tonsils and cervical lymph nodes of patients with stroke [26]. All these antigens are able to induce autoreactive $\mathrm{T}$ cell response. Moreover, stroke patients show consistently elevated activated (CD69+) T cells. All these lines of evidences support the notion that brain-derived antigens are one of the sources of communication between CNS and immune system.

\subsection{Brain-Immune Interaction through DAMPs}

Damage-associated molecular patterns are a set of molecules derived from stressed, injured and dead cells consisting of components such as DNA/RNA and intracellular proteins $[27,28]$. There is a variety of different DAMPs released from different types of cells and from different tissues upon injury. High-mobility group box-1 (HMGB1), ATP and S100 proteins are the most common DAMPs that critically influence immune response after brain injury. Following is a very brief description of some important DAMPs implicated in mediating immune responses of the injured brain.

\subsubsection{Adenosine Triphosphate (ATP)}

Cerebral ischemia leads to rapid energy failure, loss of ionic gradient, depolarization and depletion of intracellular ATP and its outflow into the interstitial space [29]. Elevated extracellular ATP acts on purinergic receptors and activate immune cells leading to release of proinflammatory cytokines and activation of inflammasome in neurons and astrocytes [30]. Interestingly, systemic administration of ATP leads to poor outcome after experimental stroke [31] and an antagonist of ATP receptor P2X7 shows protective effect in a model of transient global ischemia via dampening the inflammatory response [32].

\subsection{2. $\mathrm{S} 100 \mathrm{~B}$}

S100B is another DAMP that is mainly expressed in astrocytes in CNS and is released during cerebral ischemia. S100B has been an established surrogate marker for the severity of brain injury and predictive biomarker for the prognosis of stroke [33]. Mice over expressing S100B protein have shown enlarged infarct size after permanent MCA occlusion [34]. S100B can bind to microglial and macrophage receptor RAGE that activates downstream transcription factors including NF- $\mathrm{KB}$ and $\mathrm{AP}-1$ as well as the expression of proinflammatory cytokines IL-1 $\beta$ and TNF- $\alpha$ [35].

\subsubsection{High-Mobility Group Box-1 (HMGB1)}

HMGB1 is another important DAMP that is expressed in all nuclear cells and binds to DNA to regulate gene transcription. During cell death, extracellular release of HMGB1 functions as a potent proinflammatory molecule. HMGB1 can bind to multiple receptors including TLR-4, TLR-2, TLR-9 and RAGE to activate microglia and macrophages. Pharmacological interventions to block HMGB1 have shown a reduction in infarct size [12] and a genetic deletion of its receptor RAGE, similarly, has reduced ischemic brain damage in a mouse model of cerebral ischemia [12]. Interestingly, RAGE expression on infiltrating cells is required to mediate post-stroke inflammation [12] revealing the importance of HMGB1 and RAGE axis to mediate neuronal-glial/macrophage cross talk [36].

\subsubsection{Peroxiredoxins}

Peroxiredoxins (Prx) are a family of intracellular antioxidant proteins, which upon extracellular release behave as potent DAMPs to upregulate inflammation [37]. In ischemic stroke patients, high levels of Prx- 1 and low levels of Prx-5 are reported [38,39]. In a MCAO model of ischemic stroke, peroxiredoxin proteins such as Prx-1, Prx-2, Prx-5 and Prx-6 were found to be released from the injured brain cells and led to the increased expression of proinflammatory cytokines such as IL-23 from macrophages owing to the ligation of TLR-2 and TLR-4 [37]. 


\subsubsection{Cytokines as DAMPs}

Both interleukin (IL)- $1 \alpha$ and IL-33 belong to IL-1 family of cytokines and are dualfunction alarmins $[28,40]$. IL-1 $\alpha$ released from necrotic cells upregulates inflammation and leads to a robust infiltration of neutrophils [41]. Both the precursor and the active form of IL- $1 \alpha$ after cleavage of around 100 amino acids from the $\mathrm{N}$-terminus are found to mediate sterile inflammation [42]. IL-1 $\alpha$ has been found as the dominant form of IL-1, whose expression is upregulated in microglia as early as $4 \mathrm{~h}$ after ischemia-reperfusion insult in areas of focal neuronal damage and penumbra [43]. Similarly, in a subtype of hemorrhagic stroke, in subarachnoid hemorrhage (SAH), IL- $1 \alpha$ has also been shown to upregulate the early inflammation and later on, was also associated with a most frequent and feared complication of SAH-the cerebral vasospasm (CVS) [28]. However, contrary to this, intravenous or intra-arterial exogenous administration of IL- $1 \alpha$ in subpathological doses offers neuroprotection and neurorestoration in both acute and subacute phases of experimental ischemic stroke [44].

Despite being nominated as a dual-function alarmin like IL- $1 \alpha$, the role of IL-33, its receptor ST2 (suppressor of tumorigenicity 2) and soluble decoy receptor sST2 after ischemic stroke is controversial $[28,40,45,46]$. IL-33 promotes Th2 response and modulates microglia/macrophages to M2 phenotype [45].

\subsubsection{Extracellular-Matrix-Derived DAMPs}

Among the expanding list of DAMPs, various matricellular DAMPs such as fibronectin, tenascin $\mathrm{C}$, heparan sulphate, biglycan, versican, and hyaluronan have been described to upregulate inflammation after brain injury [28,46]. Hyaluronan, a component of extracellular matrix that upregulates inflammation via TLR-4 mediated pathway, has been shown to increase in the plasma of acute stroke patients [47,48]. Previously, a study has shown increased levels of serum hyaluronan after ischemic stroke over several days, peaking around day 7 , and also in the brain tissues harvested upon autopsy after ischemic stroke [49]. Similarly, hyaluronan expression was upregulated after experimental ischemic stroke [50]. Tang and colleagues have found an inverted U-shaped association between plasma hyaluronan and clinical outcome suggesting lower and higher plasma hyaluronan levels tend to associate with poor clinical outcome [48]. Interestingly, inhibition of hyaluronidase, the enzyme responsible for the liberation of hyaluronan fragments from the extracellular matrix, has been shown to improve the functional outcomes after ischemic stroke [51]. Expression of another extracellular matrix DAMP, tenascin C, was found to upregulate after experimental ischemic stroke, and interestingly, the knockout of tenascin $\mathrm{C}$ compromised the exploratory and surveillance activity of the microglia and led to the increased infiltration of peripheral leukocytes, particularly $T$ cells [52]. In a subtype of hemorrhagic stroke, the subarachnoid hemorrhage, tenascin $C$ has been shown to be associated with neuroinflammation, BBB disruption, neuronal apoptosis, cerebral vasospasm and neurological deficits via upregulation of MAPKs and NFKB [53]. A recent investigation showed neuroprotection, reduction in infarct sizes, protection of the $\mathrm{BBB}$, improved motor functions and increased survival upon siRNA-mediated knockdown of tenascin $C$ in experimental ischemic stroke [54]. Interestingly, plasma tenascin $C$ has also been shown to be an independent predictor of futile recanalization after acute ischemic stroke upon endovascular thrombectomy [55].

\subsection{Brain-Immune Interaction through Immune Signaling Molecules}

Signaling molecules such as cytokines and chemokines released from brain cells can stimulate peripheral and central immune cells, and increased expression of adhesion molecules facilitates the infiltration of leukocytes in the damaged brain. IL- $1 \beta$ is a potent proinflammatory cytokine that can induce release of other proinflammatory cytokines such as IL- 6 and TNF- $\alpha$, which subsequently activate peripheral immune cells [56]. TNF- $\alpha$ is acutely and chronically expressed by neurons, astrocytes and microglia after cerebral ischemia, and is implicated in mediating brain injury through several mechanisms such 
as BBB disruption, activation of leukocytes and glia, enhanced expression of adhesion molecules, thrombogenesis, apoptotic neuronal death, promotion of glutamatergic excitotoxicity through increased expression of AMPA receptors and inhibition of inhibitory GABA receptors [57]. Experimental cerebral ischemia demonstrates expression of TNF- $\alpha$ as early as $1 \mathrm{~h}$ after ischemia induction, reaching maximum at $12 \mathrm{~h}$ and persisting till day 5 [57]. TNF- $\alpha$ acts in synergism with IL-1 $\beta$ to enhance neuroinflammation and brain damage after ischemic stroke [57]. The detrimental effects of IL-1 $\beta$ include increased expression of cytokines, chemokines, adhesion molecules, activation of matrix metalloproteinases, disruption of BBB, enhanced leukocyte infiltration, platelet activation, decreased neurogenesis and decreased flow of the blood [58]. Along with TNF- $\alpha$ and IL-1 $\beta$, IL-6 is also upregulated during the acute inflammatory phase after ischemic stroke and accumulating evidence suggests that elevated IL- 6 during acute ischemic stroke is associated with poor functional outcomes $[59,60]$. Experimental studies suggest neuronal expression of IL-6 as early as $3.5 \mathrm{~h}$ after cerebral ischemia, peaking at $24 \mathrm{~h}$ and persisting till day 7 [60]. Glial cells, infiltrating monocytes and vascular endothelial cells also contribute to IL-6 expression after experimental cerebral ischemia [60].

Damaged cells during cerebral ischemia release a variety of chemokines with homeostatic or inflammatory function. Chemokines including macrophage inflammatory protein$1 \alpha$ (MIP-1 $\alpha$ or CCL3), monocyte chemotactic protein-1 (MCP-1 or CCL2) and regulated upon activation, normal T-cell expressed, and secreted (RANTES or CCL5) have shown to be released during different models of stroke [61,62]. Interestingly, CCL5 was deposited in cerebral vasculature and elevated in systemic circulation and associated with recruitment of leukocytes in mouse models of systemic inflammation and stroke $[9,13]$. Blocking CCL5 led to a decreased leukocyte infiltration in the ischemic brain and conferred neuroprotection $[9,13]$. During systemic inflammation, the number of circulating leukocytes is dramatically elevated and CCL5 has been suggested to induce MMP-9 release from leukocytes causing BBB disruption $[63,64]$. Interestingly, a concomitant influenza A virus infection and stroke led to elevated systemic MMP-9 levels that were associated with increased BBB disruption and intracerebral bleeding after thrombolysis [65]. CCL2 is another chemokine that is a potent mediator of macrophage infiltration into the ischemic tissue. CCL2-deficient mice have been shown to have reduced infiltration of inflammatory cells in the ischemic area and decreased infarct size [66,67]. Similarly, CCL3 is associated with accumulation of monocytes in the ischemic area [68] and CXCL8 recruit neutrophils to the site of ischemia via CXCL8 receptor $[69,70]$. Furthermore, cerebral ischemia leads to upregulated expression of adhesion molecules on the brain endothelial cells that facilitate trans-endothelial migration. Intercellular adhesion molecule-1 (ICAM-1), P-selectin, E-selectin and integrins have been demonstrated to be overexpressed in animal models of cerebral ischemia and interference with these adhesion molecules reduces leukocyte infiltration and tissue injury [71,72]. Evidence suggests an early expression of P-selectin within 15 min and E-selectin after $2 \mathrm{~h}$ of ischemia on endothelial cells, which facilitates leukocyte recruitment and activation in the area of ischemic damage [73]. The above-mentioned evidence highlights the possible therapeutic options in modulating the cross talk between injured brain and immune cells through interfering with cytokines, chemokines and adhesion molecules.

\subsection{Brain-Immune Interaction via Autonomic Nervous System}

The rapid nature of signal transduction in the autonomic nervous system (ANS) suggests that both sympathetic and parasympathetic nervous systems are important gateways for the fast communication between the brain and immune system to mediate immune responses $[74,75]$. The vagus nerve originating from the brain stem modulates the immune response through the inflammatory reflex, which inhibits cytokine release and reduces inflammation associated tissue injury [76]. Several immune cells including macrophages and $\mathrm{T}$ cells are functionally innervated by splenic nerve fibers responsive to vagus nerve stimulation [77]. Vagus nerve fibers terminate in celiac ganglia projecting on to the cell 
bodies of the splenic nerve fibers that innervate the spleen. The splenic fibers from the celiac ganglia are adrenergic in nature and release norepinephrine. However, these splenic fibers innervate $\mathrm{T}$ cells in the white pulp region of the spleen, which produce acetylcholine upon splenic fibers stimulation. Hence, acetylcholine producing memory T-cells in spleen play an integral part of inflammatory reflex [76]. Production of acetylcholine from T-cells, inhibits production of cytokines from macrophages through activating nicotinic acetyl choline receptor (nACh) $\alpha 7$ subunit [78]. Ay et al., have demonstrated that vagus nerve stimulation provides neuroprotection in cerebral ischemia through an unknown mechanism [79]. We have previously shown that treatment with GTS-21, a nicotinic acetylcholine receptor (nACh) $\alpha 7$ subunit agonist dampened the systemic inflammatory response and reduced infarct size in a mouse model of systemic inflammation and stroke [13]. On the contrary, around $98 \%$ of nerve fibers innervating the spleen are sympathetic in nature and activate smooth muscle cells via $\alpha-1$ receptors. Moreover, sympathetic activity can influence the function of invariant natural killer $\mathrm{T}$ cells in liver, leading to systemic immune suppression via elevated interferon-gamma (IFN- $\gamma$ ) after experimental cerebral ischemia [80]. Interestingly, blocking $\beta$-adrenergic receptors with propranolol or depletion of adrenergic nerve fibers in the liver reversed the phenotype of systemic immune suppression and decreased bacterial infections [80]. Inhibition of $\alpha-1$ adrenergic receptor with prazosin or application of panadrenergic receptor blocker carvedilol reduced the infarct size in experimental ischemia [81]. All these lines of evidence support the notion that inflammatory reflex could be a relevant mean of interaction between CNS and immune system, and could be exploited as therapeutic target to reduce brain damage during cerebral ischemia.

\section{Impact of Systemic Inflammation and Infiltrated Immune Cells on Ischemic Brain}

The brain and immune system communicate through the above-discussed ways and respond to CNS injury. Both the innate and adaptive immune systems have profound influence on the injured brain and deeply affect the clinical outcome via influencing both neurodegeneration in acute phase and regeneration during post-stroke recovery phase.

\subsection{Impact of Innate Immune Cells on Ischemic Brain}

The resident microglial cells are rapidly activated after cerebral ischemia and express activation markers including MHC-II, Iba- 1 and CD11b. Activation of microglia is evident before the neuronal demise and precedes the recruitment of peripheral macrophages [82,83]. Soon after the ischemic insult, activated microglia show extensive arborization and exploratory behavior, and later on dearborization and amoeboid transformation [84]. Microglia are associated with the prompt release of proinflammatory cytokines, display early phagocytic and neurotoxic activities [85]. Reactive microglia/macrophages have been detected to peak around four days after experimental cerebral ischemia [86]. However, depletion of microglia after stroke worsens the damage, and evidence suggests microglia later on contribute towards anti-inflammatory effects through inhibition of astrocytes, phagocytosis of dead cells and neutrophils, release of anti-inflammatory and neurotrophic factors [85]. Neuronal interactions with microglia, for instance, loss of CSF1R ligand IL-34 due to the death of neurons, cause microglial depletion, whereas loss of neuronal CX3CL1 and CD200 increases microglial activation [85].

In contrast, the bone-marrow-derived macrophages infiltrate over a period of hours to days and peak at around day 3-7 [83]. Monocyte infiltration was detected as early as within $24 \mathrm{~h}$ after cerebral ischemia [86]. Additionally, during the acute phase, the ischemiareperfusion injury also activates perivascular macrophages and mast cells [87]. Mast cells degranulate releasing histamine, proteases and $\operatorname{TNF} \alpha$, whereas perivascular macrophages release proinflammatory cytokines. Consequently, these stimuli lead to upregulation of adhesion molecules on endothelial cells and contribute to BBB disruption, thus, paving the way for the recruitment of neutrophils, monocytes and lymphocytes [87].

Neutrophils represent the earliest peripheral myeloid cells recruited after cerebral ischemia and can be detected within an hour in microvessels, reaching a peak 1-3 days 
after ischemic stroke $[85,86]$. The detrimental effects of neutrophils are owing to the release of granules containing metalloproteinases (MMP9), elastase and cathepsin G, in addition to the production of highly reactive oxygen and nitrogen species. Interestingly, neutrophils also undergo netosis, a unique type of death which results due to the formation of neutrophil extracellular traps (NETs) which are extracellularly displayed nuclear and mitochondrial DNA scaffolds studded with cytotoxic histones and proteases [85]. NETs have been shown to promote thrombosis and impair thrombolysis with tPA [86]. However, tPA promotes neutrophil transmigration, and neutrophilia or higher neutrophil to lymphocyte ratio are associated with a risk of ischemic to hemorrhagic transformation after tPA administration [86]. Neutrophils showing alternative activation and presenting with upregulated expression of Arg1 and YM1, displaying anti-inflammatory and repair activities, reduced oxidative burst and netosis, need further investigation to delineate the possible neuroprotective effects $[85,86]$.

Both resident microglia and macrophages clear the debris of infarcted tissue [88]. Depending on the nature of the environment, microglia and macrophages can polarize to the classical/inflammatory or the alternate/anti-inflammatory cells. A growing body of evidence shows maintaining the microglia in M2-phenotype (anti-inflammatory microglia) protects neurons against ischemia. We have already demonstrated that a shift of balance of monocytes/macrophages towards alternate/M2- phenotype showed a robust neuroprotection in a mouse model of cerebral ischemia [15]. However, neutrophils infiltrate rapidly within few hours after stroke and peak at day 1-3 [89]. Adhesion molecules such as ICAM-1 and P-selectin facilitate the neutrophil infiltration [90,91]. Infiltrating neutrophils release NO and MMP-9, which play a key role in disrupting BBB. Elevated systemic MMP-9 during concomitant stroke and systemic inflammation correlates with thrombolysis-associated intracerebral bleeding [65]. Furthermore, depletion of neutrophils with an antibody-based approach reduced the infarct size and brain edema in an experimental cerebral ischemia [92]. Dendritic cells from the systemic circulation also infiltrate early at day 1 and reach to a peak at day 3-7, and being antigen-presenting cells modulate the adaptive immune response [93]. Based on above findings, the suppression of neutrophils and polarization of microglia and macrophages towards M2 type might be possible therapeutic options to achieve better outcomes after stroke.

\subsection{Impact of Adaptive Immunity (Immune Cells) on Ischemic Brain}

The adaptive immune system is activated by antigens that are released from the ischemic brain. Lymphocytes start accumulating in ischemic brain within $24 \mathrm{~h}$ after stroke [94] and play a critical role in defining the clinical outcome, especially at a later stage. Rag 1 knockout mice lacking mature lymphocytes showed smaller infarct size and better clinical outcome after experimental stroke [95] and implantation of CD3+ T lymphocytes into Rag 1 knockout mice abolished this protective effect [95]. Interestingly, mice deficient in either CD4+ T helper cells or CD8+ T cells exhibited significantly smaller infarct sizes [96] and a selective depletion of either CD4+ or CD8+ cells using antibodies, remarkably reduced the infarct volume in a model of permanent MCAO [97], demonstrating the detrimental role of both subpopulations of $\mathrm{T}$ cells. On the other hand, regulatory $\mathrm{T}$ cells (Tregs), a subpopulation of CD4+ T helper cells account for only $10 \%$ of circulating CD4+ Thelper cells, mediated neuroprotection and improved neurological outcome via production of anti-inflammatory cytokines [11]. Recent investigations suggest that Tregs with brain specific signatures were recruited during the chronic phase of stroke and protected against astrogliosis, suppressed neurotoxic astrocytes, and promoted functional recovery [98]. These evidences suggest that a therapeutic approach targeting a selectively specific subpopulation of T cells may provide options to improve post-stroke outcomes. 


\section{Brain-Immune Interaction after Cerebral Ischemia and Therapeutic Options}

Post-stroke neuronal death is a progressive process and continues over days to weeks after the initial insult [99]. Keeping in view the brain-immune interaction, there are multiple options that could be of therapeutic interest.

\subsection{Targeting DAMPs and Their Receptors}

Necrotic cells release highly active proinflammatory danger signal molecules that enhance the neuroinflammation through receptors like RAGE and TLRs by activating multiple downstream pathways in the neural cells [7,12]. Blocking the release of danger signal molecules or strategies to neutralize them with antibodies or interference with their receptors to block the cellular effects could be a possible therapeutic implication.

\subsection{Targeting Immune-Signaling Molecules}

Several immune-signaling molecules, such as cytokines, chemokines and adhesion molecules, play an important role in orchestrating the inflammatory response after cerebral ischemia. For instance, TNF- $\alpha$ antagonism through soluble TNF receptor (sTNFR) or monoclonal antibodies directed against TNF- $\alpha$ provide neuroprotective effects after cerebral ischemia [57]. Etanercept, an inhibitor of TNF- $\alpha$, shows neuroprotection after experimental cerebral ischemia and also improves clinical outcomes in the context of chronic stroke $[100,101]$. As mentioned above, TNF- $\alpha$ enhances the detrimental effects of IL- $1 \beta$, and antagonism of IL-1 $\beta$ either through anti-IL- $1 \beta$ antibodies or administration of the IL-1Receptor antagonist (IL-1RA) has been shown to be neuroprotective and improves outcomes after ischemic stroke [58]. Elevation of IL-6 levels also accompany TNF- $\alpha$ and IL-1 $\beta$ levels after ischemic stroke; however, antagonism of IL- 6 has yielded conflicting results in the experimental setting. Administration of IL-6 receptor antagonist (IL-6RA) monoclonal antibody in a mouse model of ischemic stroke was found to increase the infarct volume, peri-infarct apoptosis and motor dysfunction [102]. However, recent studies have shown neuroprotective effects of an FDA-approved IL-6RA, tocilizumab, after experimental cerebral ischemia $[103,104]$. In one study, rats underwent cerebral ischemia after 7 days of treatment with tocilizumab, and tocilizumab administration prevented apoptosis [103]. Administration of tocilizumab $4 \mathrm{~h}$ after cerebral ischemia induction was found to protect against acute and long-term larger brain infarcts and brain atrophy in aged male mice [104].Various experimental and clinical studies have also targeted adhesion molecules to ameliorate the effects of infiltrating immune cells in the CNS after cerebral ischemia. Antibody-mediated antagonism of P-selectin and E-selectin was found to be neuroprotective after experimental cerebral ischemia [105,106]. However, a clinical phase II study investigating the mucosal tolerance and shift of the Th1 response to Th2 upon repeated intranasal spray of E-selectin to prevent recurrent strokes was terminated without disclosing any findings [107]. In a study targeting endothelial integrin ligand ICAM-1, anti-ICAM-1 murine antibody was shown to be effective in experimental cerebral ischemia, but offered no neuroprotective benefits in the clinical phase III trial, rather was associated with adverse clinical outcomes [108]. Several integrins such as LFA-1 (CD11a CD18, $\alpha$ L $\beta 2)$, Mac-1 (CD11b CD18, $\alpha$ M 32 ), VLA-4 (CD49d/CD29, $\alpha 4 \beta 1)$, and VLA-5 (CD49e/CD29, $\alpha 5 \beta 1$ ) have been shown to be upregulated after cerebral ischemia and their inhibition has been shown to confer neuroprotective effects after experimental cerebral ischemia [73]. However, fruitful clinical studies for the treatment of ischemic stroke that are based on targeting integrins are still underdevelopment [73].

\subsection{Targeting the Autonomic Nervous System}

Experimental data suggest that the vagus nerve controls the release of multiple cytokines from peripheral macrophages through inflammatory reflex. Stimulation of nicotinic acetyl choline receptor (nACh) $\alpha 7$ subunit is a key in the vagus control of immunity. Vagus nerve stimulation can protect the brain from ischemia and in line with these findings, blocking the activity of sympathetic nervous system can protect against the post-stroke 
immune depression and infection-mediated deaths $[79,80]$. Besides vagus nerve stimulation, selectively targeting nicotinic acetyl choline receptor (nACh) $\alpha 7$ subunit or adrenergic receptors could also be a therapeutic implication for the treatment of stroke.

\subsection{Targeting Polarization of Microglia/Macrophages towards M2 Type Phenotype}

The polarization towards a specific population depends on the microenvironment. M2 type microglia can attenuate activation of invading inflammatory cells via release of IL-10 and TGF- $\beta[11,109]$. Interestingly, monocytes/macrophages express molecules that enhance angiogenesis such as VEGF, TGF- $\beta$ and MMP-9 $[110,111]$ providing post-stroke recovery. Moreover, monocytes and microglia release neural trophic factors such as BDNF, CCL2 and SDF-1 to enhance neurogenesis and facilitate migration of newborn neurons [112-114]. Interestingly, CD14+ monocytes have themselves the capacity to differentiate into neuronal lineage [115]. Furthermore, in the process of remyelination, oligodendrocyte precursor cells (OPC) are necessary. M1 type microglia and macrophages cause oligodendrocyte precursor cell (OPC) death, whereas M2 type cells enhance chemotaxis and differentiation of OPC cells [116,117]. IL-4 and IL-33 administration was found to polarize towards M2 microglia/macrophages and confers neuroprotection after cerebral ischemia $[45,118]$. Besides targeting molecules released by necrotic tissue, polarization of microglia and macrophages towards a beneficial subtype could be an interesting strategy to treat stroke.

\subsection{Targeting Polarization of Specific T Cell Response towards Th2 and Regulatory T-Cells}

Depending upon microenvironment and cellular interactions with innate immune cells, T helper cells can polarize towards Th1, Th2, Th17 or towards regulatory T cells. The polarization of $\mathrm{T}$ cells can critically influence progression of injury, angiogenesis and tissue repair. On one hand, the polarization of T helper cells towards Th1 type CD4+ cells inhibit angiogenesis through the release of IFN- $\gamma$ [119] and on the other hand, Th2 type CD4+ cells and regulatory T cells promote angiogenesis via releasing VEGF and TGF- $\beta[120,121]$. Moreover, Th1 type cells have the potential to induce demyelination and Th2 type cells improve OPCs [116] to enhance remyelination and regeneration. Hence, either a selective polarization of T cells towards Th2 type and T regulatory cells or adoptive transfer of these cells could be an important therapeutic implication.

\subsection{Evidence of Stem Cell Signals to Instruct Immune Micro Milieu}

Neurogenesis is complex process where new cells are born from stem cells in the brain. Despite the ongoing debate regarding the biological relevance of adult neurogenesis [122], accumulating evidence suggests misregulated neurogenesis is promoting aging-related brain diseases [123]. More recently, mostly emerging from discoveries in cancer research, the fatal tango pair of stem cells and immunity [124] is brought into attention as how stem cell signals may fundamentally contribute to disease course and therapy resistance [125-127]. Some most recent observations indicate the importance of stem cell factors in immune regulation during stroke [128-130] and brain diseases including non-cancer problems [131-134].

Many different types of stem-cell-based therapies consisting of neural stem cells, mesenchymal stem cells, embryonic stem cells, and human induced pluripotent stem-cellderived neural stem cells have been evaluated as a potential therapy against ischemic stroke both in preclinical and clinical settings [135]. However, the time frame windows for implementation of these stem cell based therapies and the mechanism through which stem cells exert their beneficial effects still require further investigations. Modulation of the immune milieu by these stem cells may be one of the underlying mechanisms. Interestingly, in vitro co-culture of macrophages/microglia with mesenchymal-derived stem cells (MSCs) have shown to promote M2 microglia/macrophage polarization [128]. Similarly, in vivo transplantation of MSCs after experimental MCAO in rodents have shown decreased infarct volumes and increased functional recovery through polarization of macrophages/microglia towards the neuroprotective and neuroregenerative M2 phe- 
notype [128]. Intriguingly, alternatively activated microglia serve as the source of IGF-1 (insulin like growth factor-1) in the subventricular zone (SVZ) and promote proliferation, differentiation and migration into the striatum after experimental ischemic stroke [136]. Similarly, anti-inflammatory Tregs were shown to promote neural stem cells proliferation in the SVZ after experimental cerebral ischemia through IL-10 [137]. An experimental cerebral ischemia study involving administration of bone marrow mononuclear cells administration showed that the proliferation of neural progenitor/stem cells was dependent on the proliferation of endothelial cells [138]. Further, investigations seeking efficacy, time frame windows, stem-cell-based therapy alone or in combination with thrombolytic or endovascular thrombectomy, and the potential mechanisms of stem-cell-based therapies are urgently required $[135,139]$. Our limited knowledge on stem cell signal driven pathology presents a lack of literature evidence.

\section{Discussion}

Stroke remains the major contributor to worldwide mortality and morbidity despite enormous advancements in biomedical sciences and the availability of limited clinical approaches to treat it. State of the art research suggests a critical role of inflammation after stroke that determines the clinical outcome [140]. Discerning various endogenous mechanisms that limit or neutralize excessive proinflammatory responses could lead to novel therapeutic options for stroke. Additionally, several risk factors e.g., inheriting various class I HLA molecules and killer immunoglobulin like receptors (KIRs) alleles, which play important role in T cell and NK cell responses, may determine the protective or detrimental impact after ischemic stroke [141]. All the evidences presented above highlight an importance of various axes of brain-immune interactions in mediating the disease and contributing to stroke outcomes. Modulation of these interactions in a correct way could serve as therapeutic interventions. Figure 1a summarizes the time course of major immune cell types after cerebral ischemia and Figure $1 \mathrm{~b}$ shows the major molecular and cellular targets that may be targeted to modulate the brain-immune interactions after stroke.

Various DAMPs can be released after ischemic insult into the periphery and may activate the peripheral immune system. Owing to compromised BBB, several antigens specific to CNS can be unveiled for the development of autoreactive adaptive immunity. Several signaling molecules such as cytokines, chemokines and adhesion molecules may also play an important role in immune activation and inflammation. The innate immune cells such as microglia/macrophages can polarize to neurodamaging (M1) and neuroprotective (M2) phenotypes as do the adaptive CD4+ T helper cells to Th1, Th2 and Th17 cells, respectively. Intriguingly, discovery of the autonomic reflex control of immunity provides another prompt mechanism of regulation of the inflammatory cascades. So, ample evidence highlights the critical roles of these brain-immune interactions, which can be modulated to develop future promising therapeutic entities.

Among various DAMPs, HMGB1 represents a prototypical protein transcription factor that has been increasingly investigated for its role in post-ischemic inflammation and its modulation as a therapeutic target. For instance, antibody-mediated neutralization of HMGB1 or its antagonism via HMGB1 box A or glycyrrhizin can be neuroprotective in ischemic stroke models [12,142]. Interestingly, ameliorating the HMGB1-RAGE interaction via administering a decoy soluble RAGE receptor was found to be neuroprotective in ischemic stroke model [12]. Similarly, peroxiredoxins were released after $12 \mathrm{~h}$ of stroke onset and antibody mediated neutralization of peroxiredoxins downregulated the inflammation and prevented ischemic brain damage [37]. Interestingly, upregulation of the scavenger receptors such as MSR1 on infiltrating myeloid cells by modulating the Mafb expression through administration of retinoic acid receptor (RAR) agonist Am80 led to the enhanced clearance of various DAMPs (HMGB1, peroxiredoxins, S100A8, S100A9) from the ischemic brain and prevented delayed inflammation and damage [143]. 

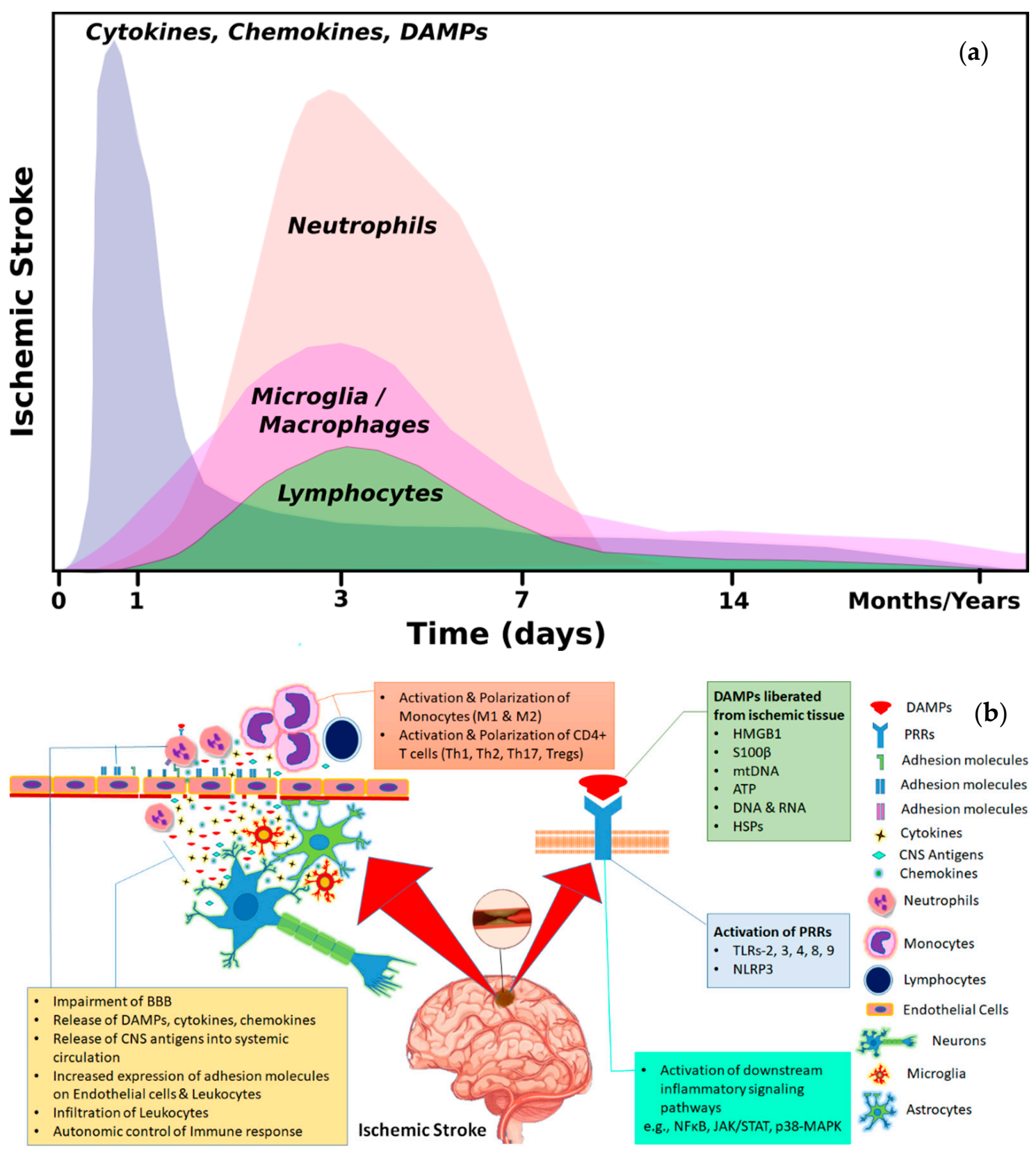

Figure 1. (a). Temporal dynamics of major immune cell types and inflammatory mediators after ischemic stroke. The release of DAMPs from the ischemia injured cerebral tissue leads to the activation of microglia/macrophages which release chemokines and cytokines leading to the infiltration of peripheral immune cells. Neutrophils and monocytes/macrophages are recruited along with lymphocytes from the periphery to the ischemic cerebral tissue. (b). A schematic representation of brain-immune interactions taking place after cerebral ischemia. Brain-derived antigens, DAMPs, cytokines and chemokines are released into systemic circulation through the impaired blood-brain barrier (BBB) after cerebral ischemia and lead to activation and polarization of immune cells (M1/M2, Th1/Th2, Th17/Tregs). Increased expression of adhesion molecules on endothelial cells and immune cells lead to increased infiltration by the leukocytes in the already damaged ischemic brain causing secondary damage. DAMPs: damage-associated molecular patterns; PRRs: pattern recognition receptors; TLRs: Toll like receptors; HSPs: heat shock proteins; M1: classically activated proinflammatory monocytes/macrophages; M2: alternatively activated anti-inflammatory monocytes/macrophages; Tregs: T regulatory cells; Th cells: CD4+ T helper cells.

Microglial/macrophage activation inhibition via administration of minocycline was found to be neuroprotective in two phase two clinical studies [144,145]. Macrophages/microglia may be polarized to neuroprotective, alternatively activated (M2) phenotype either by the use of miRNAs such as miRNA-181a or exploiting the epigenetic control of macrophage polarization 
to achieve better outcomes in stroke. Alternatively activated (M2) microglia/macrophage polarization has also been shown in experimental stroke models with drugs such as minocycline, azithromycin, exendin-4, metformin and rosiglitazone [146,147]. Several traditional and Chinese alternative medicine ingredients have shown the potential to promote alternatively activated (M2) response and neuroprotection in experimental ischemic stroke settings e.g., ginkgolide B, malibatol A, hyperforin, thiamet $G$ and noggin [147]. Non-invasive vagus nerve stimulation may also be employed to polarize macrophages to alternatively activated (M2) type that affords neuroprotection against ischemia-reperfusion injury [148]. Several other agents discussed above can modify the autonomic reflex and provide neuroprotective effects in ischemic brain injury.

Depletion of $\mathrm{T}$ cells from the ischemia afflicted brain represents another potential therapeutic intervention [149]. Among different T helper cell subsets, promotion of Th1 cell response (proinflammatory) has been shown to increase the infarct volumes and its suppression with a promotion of Th2 or Treg responses (anti-inflammatory) offered neuroprotection in ischemic stroke models [11,150-153]. A few agents such as glatiramer acetate or statins as well as aluminum hydroxide (used as vaccine adjuvant) have been shown to induce Th2 response leading to neuroprotection and regeneration [150].

Several proinflammatory mediators released after ischemic brain insult represent attractive targets of intervention. For instance, the effects of IL-1 $\beta$ released after stroke can be neutralized by administration of IL-1 $\beta$ receptor antagonist. Preclinical results and a clinical phase II study have demonstrated beneficial and safety potential of IL- $1 \beta$ receptor antagonist after ischemic stroke $[58,154]$. Over the past years, an array of neutralizing antibodies have been developed that target a wide range of proinflammatory mediators including TNF- $\alpha$, IL-12, IL-23, IL-17, and are under investigation in clinical trials for various neurological and other diseases [155-158]. Anti-adhesion molecules antibodies may also be employed to curb the inflammatory response such as Natalizumab, anti- $\alpha 4$ integrin, have been found to be effective in the setting of multiple sclerosis [140]. However, the clinical development of effective anti-adhesion molecules against ischemic stroke is still awaited [73]. Accumulating evidences support an important role of inflammation that is upregulated via various brain-immune interactions as discussed above and represents important therapeutic targets of intervention to achieve better outcomes after stroke.

Given the importance of stem cells in the brain for various brain functions, stimulating or modulating the activity of those pathways in the context of the disease, is an attractive opportunity to sustainably intervene in the neuro-immune axis. Although, the field is far from a mutual consensus on how stem cell, or stem cell signals, instruct neuroimmunity, the authors believe further research in this segment shall lead to innovative new traits to treat or improve therapy surveillance of cerebral ischemia. The inclusion of stem cell investigation in inflammation-directed projects on cerebral pathologies should be promoted.

\section{Conclusions}

Recent advancements in experimental research have unveiled the interactions taking place between the injured brain and immune system after ischemic stroke. These interactions represent potential modulatable targets of therapeutic intervention using pharmacological agents with an ultimate goal to improve the quality of life of stroke-afflicted patients and reduce mortality.

Author Contributions: S.M. conceived the idea and drafted the manuscript. S.R.C. significantly contributed to the draft. U.D.K. also contributed to the draft and critically reviewed the manuscript. M.N. and D.H. critically reviewed the final draft of the manuscript. All authors have read and approved the final draft. All authors have read and agreed to the published version of the manuscript.

Funding: The APC was funded by University of Helsinki.

Institutional Review Board Statement: Not applicable.

Informed Consent Statement: Not applicable. 


\section{Data Availability Statement: Not applicable.}

Acknowledgments: Open access funding provided by the University of Helsinki, Helsinki, Finland.

Conflicts of Interest: The authors declare no conflict of interest.

\section{References}

1. Lloyd-Jones, D.; Adams, R.; Carnethon, M.; De Simone, G.; Ferguson, T.B.; Flegal, K.; Ford, E.; Furie, K.; Go, A.; Greenlund, K.; et al. Heart disease and stroke statistics-2009 update: A report from the American Heart Association Statistics Committee and Stroke Statistics Subcommittee. Circulation 2009, 119, e21-e181. [CrossRef]

2. Dirnagl, U.; Iadecola, C.; Moskowitz, M.A. Pathobiology of ischaemic stroke: An integrated view. Trends Neurosci. 1999, 22, 391-397. [CrossRef]

3. Qureshi, A.I.; Mendelow, A.D.; Hanley, D.F. Intracerebral haemorrhage. Lancet 2009, 373, 1632-1644. [CrossRef]

4. Campbell, B.C.V.; Mitchell, P.J.; Kleinig, T.J.; Dewey, H.M.; Churilov, L.; Yassi, N.; Yan, B.; Dowling, R.J.; Parsons, M.W.; Oxley, T.J.; et al. Endovascular Therapy for Ischemic Stroke with Perfusion-Imaging Selection. N. Engl. J. Med. 2015, 372, 1009-1018. [CrossRef]

5. Saver, J.L.; Goyal, M.; Bonafe, A.; Diener, H.-C.; Levy, E.I.; Pereira, V.M.; Albers, G.W.; Cognard, C.; Cohen, D.J.; Hacke, W.; et al. Stent-Retriever Thrombectomy after Intravenous t-PA vs. t-PA Alone in Stroke. N. Engl. J. Med. 2015, 372, 2285-2295. [CrossRef]

6. Hacke, W.; Kaste, M.; Bluhmki, E.; Brozman, M.; Dávalos, A.; Guidetti, D.; Larrue, V.; Lees, K.R.; Medeghri, Z.; Machnig, T.; et al. Thrombolysis with Alteplase 3 to 4.5 Hours after Acute Ischemic Stroke. N. Engl. J. Med. 2008, 359, 1317-1329. [CrossRef]

7. Herrmann, O.; Baumann, B.; de Lorenzi, R.; Muhammad, S.; Zhang, W.; Kleesiek, J.; Malfertheiner, M.; Kohrmann, M.; Potrovita, I.; Maegele, I.; et al. IKK mediates ischemia-induced neuronal death. Nat. Med. 2005, 11, 1322-1329. [CrossRef] [PubMed]

8. Schneider, A.; Martin-Villalba, A.; Weih, F.; Vogel, J.; Wirth, T.; Schwaninger, M. NF-kappaB is activated and promotes cell death in focal cerebral ischemia. Nat. Med. 1999, 5, 554-559. [CrossRef] [PubMed]

9. Denes, A.; Humphreys, N.; Lane, T.E.; Grencis, R.; Rothwell, N. Chronic systemic infection exacerbates ischemic brain damage via a CCL5 (regulated on activation, normal T-cell expressed and secreted)-mediated proinflammatory response in mice. J. Neurosci. 2010, 30, 10086-10095. [CrossRef] [PubMed]

10. Inta, I.; Frauenknecht, K.; Dörr, H.; Kohlhof, P.; Rabsilber, T.; Auffarth, G.U.; Burkly, L.; Mittelbronn, M.; Hahm, K.; Sommer, C.; et al. Induction of the cytokine TWEAK and its receptor Fn14 in ischemic stroke. J. Neurol. Sci. 2008, 275, 117-120. [CrossRef]

11. Liesz, A.; Suri-Payer, E.; Veltkamp, C.; Doerr, H.; Sommer, C.; Rivest, S.; Giese, T.; Veltkamp, R. Regulatory T cells are key cerebroprotective immunomodulators in acute experimental stroke. Nat. Med. 2009, 15, 192-199. [CrossRef]

12. Muhammad, S.; Barakat, W.; Stoyanov, S.; Murikinati, S.; Yang, H.; Tracey, K.J.; Bendszus, M.; Rossetti, G.; Nawroth, P.P.; Bierhaus, A.; et al. The HMGB1 Receptor RAGE Mediates Ischemic Brain Damage. J. Neurosci. 2008, 28, 12023-12031. [CrossRef] [PubMed]

13. Muhammad, S.; Haasbach, E.; Kotchourko, M.; Strigli, A.; Krenz, A.; Ridder, D.A.; Vogel, A.B.; Marti, H.H.; Al-Abed, Y.; Planz, O.; et al. Influenza virus infection aggravates stroke outcome. Stroke 2011, 42, 783-791. [CrossRef]

14. Murikinati, S.; Jüttler, E.; Keinert, T.; Ridder, D.A.; Muhammad, S.; Waibler, Z.; Ledent, C.; Zimmer, A.; Kalinke, U.; Schwaninger, M. Activation of cannabinoid 2 receptors protects against cerebral ischemia by inhibiting neutrophil recruitment. FASEB J. 2010, 24, 788-798. [CrossRef]

15. Rahman, M.; Muhammad, S.; Khan, M.A.; Chen, H.; Ridder, D.A.; Muller-Fielitz, H.; Pokorna, B.; Vollbrandt, T.; Stolting, I.; Nadrowitz, R.; et al. The beta-hydroxybutyrate receptor HCA2 activates a neuroprotective subset of macrophages. Nat. Commun. 2014, 5, 3944. [CrossRef]

16. Mehta, S.L.; Manhas, N.; Raghubir, R. Molecular targets in cerebral ischemia for developing novel therapeutics. Brain Res. Rev. 2007, 54, 34-66. [CrossRef]

17. Hill, W.D.; Hess, D.C.; Martin-Studdard, A.; Carothers, J.J.; Zheng, J.; Hale, D.; Maeda, M.; Fagan, S.C.; Carroll, J.E.; Conway, S.J. SDF-1 (CXCL12) is upregulated in the ischemic penumbra following stroke: Association with bone marrow cell homing to injury. J. Neuropathol. Exp. Neurol. 2004, 63, 84-96. [CrossRef] [PubMed]

18. Chamorro, A.; Meisel, A.; Planas, A.M.; Urra, X.; van de Beek, D.; Veltkamp, R. The immunology of acute stroke. Nat. Rev. Neurol. 2012, 8, 401-410. [CrossRef]

19. Hanisch, U.K.; Kettenmann, H. Microglia: Active sensor and versatile effector cells in the normal and pathologic brain. Nat. Neurosci. 2007, 10, 1387-1394. [CrossRef]

20. An, C.; Shi, Y.; Li, P.; Hu, X.; Gan, Y.; Stetler, R.A.; Leak, R.K.; Gao, Y.; Sun, B.-L.; Zheng, P.; et al. Molecular dialogs between the ischemic brain and the peripheral immune system: Dualistic roles in injury and repair. Prog. Neurobiol. 2014, 115, 6-24. [CrossRef]

21. Mecha, M.; Carrillo-Salinas, F.J.; Mestre, L.; Feliu, A.; Guaza, C. Viral models of multiple sclerosis: Neurodegeneration and demyelination in mice infected with Theiler's virus. Prog. Neurobiol. 2013, 101-102, 46-64. [CrossRef] [PubMed]

22. Dittel, B.N.; Visintin, I.; Merchant, R.M.; Janeway, C.A., Jr. Presentation of the self antigen myelin basic protein by dendritic cells leads to experimental autoimmune encephalomyelitis. J. Immunol. 1999, 163, 32-39. [PubMed]

23. Bornstein, N.M.; Aronovich, B.; Korczyn, A.D.; Shavit, S.; Michaelson, D.M.; Chapman, J. Antibodies to brain antigens following stroke. Neurology 2001, 56, 529-530. [CrossRef] 
24. Dambinova, S.A.; Khounteev, G.A.; Izykenova, G.A.; Zavolokov, I.G.; Ilyukhina, A.Y.; Skoromets, A.A. Blood test detecting autoantibodies to N-methyl-D-aspartate neuroreceptors for evaluation of patients with transient ischemic attack and stroke. Clin. Chem. 2003, 49, 1752-1762. [CrossRef]

25. Tsuda, M.; Shigemoto-Mogami, Y.; Koizumi, S.; Mizokoshi, A.; Kohsaka, S.; Salter, M.W.; Inoue, K. P2X4 receptors induced in spinal microglia gate tactile allodynia after nerve injury. Nature 2003, 424, 778-783. [CrossRef] [PubMed]

26. Planas, A.M.; Gomez-Choco, M.; Urra, X.; Gorina, R.; Caballero, M.; Chamorro, A. Brain-derived antigens in lymphoid tissue of patients with acute stroke. J. Immunol. 2012, 188, 2156-2163. [CrossRef] [PubMed]

27. Schaefer, L. Complexity of danger: The diverse nature of damage-associated molecular patterns. J. Biol. Chem. 2014, 289, 35237-35245. [CrossRef]

28. Chaudhry, S.R.; Hafez, A.; Rezai Jahromi, B.; Kinfe, T.M.; Lamprecht, A.; Niemelä, M.; Muhammad, S. Role of Damage Associated Molecular Pattern Molecules (DAMPs) in Aneurysmal Subarachnoid Hemorrhage (aSAH). Int. J. Mol. Sci. 2018, 19, 2035. [CrossRef]

29. Latini, S.; Pedata, F. Adenosine in the central nervous system: Release mechanisms and extracellular concentrations. J. Neurochem. 2001, 79, 463-484. [CrossRef]

30. Silverman, W.R.; de Rivero Vaccari, J.P.; Locovei, S.; Qiu, F.; Carlsson, S.K.; Scemes, E.; Keane, R.W.; Dahl, G. The pannexin 1 channel activates the inflammasome in neurons and astrocytes. J. Biol. Chem. 2009, 284, 18143-18151. [CrossRef] [PubMed]

31. Zhang, M.; Li, W.; Niu, G.; Leak, R.K.; Chen, J.; Zhang, F. ATP induces mild hypothermia in rats but has a strikingly detrimental impact on focal cerebral ischemia. J. Cereb. Blood Flow Metab. 2013, 33, e1-e10. [CrossRef]

32. Chu, K.; Yin, B.; Wang, J.; Peng, G.; Liang, H.; Xu, Z.; Du, Y.; Fang, M.; Xia, Q.; Luo, B. Inhibition of P2X7 receptor ameliorates transient global cerebral ischemia/reperfusion injury via modulating inflammatory responses in the rat hippocampus. $J$. Neuroinflamm. 2012, 9, 69. [CrossRef] [PubMed]

33. Foerch, C.; Singer, O.C.; Neumann-Haefelin, T.; du Mesnil de Rochemont, R.; Steinmetz, H.; Sitzer, M. Evaluation of serum S100B as a surrogate marker for long-term outcome and infarct volume in acute middle cerebral artery infarction. Arch. Neurol. 2005, 62, 1130-1134. [CrossRef]

34. Mori, T.; Tan, J.; Arendash, G.W.; Koyama, N.; Nojima, Y.; Town, T. Overexpression of human S100B exacerbates brain damage and periinfarct gliosis after permanent focal ischemia. Stroke 2008, 39, 2114-2121. [CrossRef] [PubMed]

35. Bianchi, R.; Giambanco, I.; Donato, R. S100B/RAGE-dependent activation of microglia via NF-kappaB and AP-1 Co-regulation of COX-2 expression by S100B, IL-1beta and TNF-alpha. Neurobiol. Aging 2010, 31, 665-677. [CrossRef]

36. Kim, J.B.; Sig Choi, J.; Yu, Y.M.; Nam, K.; Piao, C.S.; Kim, S.W.; Lee, M.H.; Han, P.L.; Park, J.S.; Lee, J.K. HMGB1, a novel cytokine-like mediator linking acute neuronal death and delayed neuroinflammation in the postischemic brain. J. Neurosci. 2006, 26, 6413-6421. [CrossRef] [PubMed]

37. Shichita, T.; Hasegawa, E.; Kimura, A.; Morita, R.; Sakaguchi, R.; Takada, I.; Sekiya, T.; Ooboshi, H.; Kitazono, T.; Yanagawa, T.; et al. Peroxiredoxin family proteins are key initiators of post-ischemic inflammation in the brain. Nat. Med. 2012, 18, 911-917. [CrossRef]

38. Kunze, A.; Zierath, D.; Tanzi, P.; Cain, K.; Becker, K. Peroxiredoxin 5 (PRX5) Is Correlated Inversely to Systemic Markers of Inflammation in Acute Stroke. Stroke 2014, 45, 608-610. [CrossRef]

39. Richard, S.; Lapierre, V.; Girerd, N.; Bonnerot, M.; Burkhard, P.R.; Lagerstedt, L.; Bracard, S.; Debouverie, M.; Turck, N.; Sanchez, J.-C. Diagnostic performance of peroxiredoxin 1 to determine time-of-onset of acute cerebral infarction. Sci. Rep. 2016, 6, 38300. [CrossRef]

40. Hirsiger, S.; Simmen, H.P.; Werner, C.M.; Wanner, G.A.; Rittirsch, D. Danger signals activating the immune response after trauma. Mediat. Inflamm. 2012, 315941. [CrossRef]

41. Chen, C.-J.; Kono, H.; Golenbock, D.; Reed, G.; Akira, S.; Rock, K.L. Identification of a key pathway required for the sterile inflammatory response triggered by dying cells. Nat. Med. 2007, 13, 851-856. [CrossRef]

42. Kim, B.; Lee, Y.; Kim, E.; Kwak, A.; Ryoo, S.; Bae, S.H.; Azam, T.; Kim, S.; Dinarello, C.A. The Interleukin-1 $\alpha$ Precursor is Biologically Active and is Likely a Key Alarmin in the IL-1 Family of Cytokines. Front. Immunol. 2013, 4, 391. [CrossRef]

43. Luheshi, N.M.; Kovács, K.J.; Lopez-Castejon, G.; Brough, D.; Denes, A. Interleukin-1 $\alpha$ expression precedes IL-1 $\beta$ after ischemic brain injury and is localised to areas of focal neuronal loss and penumbral tissues. J. Neuroinflam. 2011, 8, 186. [CrossRef]

44. Salmeron, K.E.; Maniskas, M.E.; Edwards, D.N.; Wong, R.; Rajkovic, I.; Trout, A.; Rahman, A.A.; Hamilton, S.; Fraser, J.F.; Pinteaux, E.; et al. Interleukin 1 alpha administration is neuroprotective and neuro-restorative following experimental ischemic stroke. J. Neuroinflam. 2019, 16, 222. [CrossRef]

45. Yang, Y.; Liu, H.; Zhang, H.; Ye, Q.; Wang, J.; Yang, B.; Mao, L.; Zhu, W.; Leak, R.K.; Xiao, B.; et al. ST2/IL-33-Dependent Microglial Response Limits Acute Ischemic Brain Injury. J. Neurosci. 2017, 37, 4692-4704. [CrossRef]

46. Gülke, E.; Gelderblom, M.; Magnus, T. Danger signals in stroke and their role on microglia activation after ischemia. Adv. Neurol. Disord. 2018, 11, 1756286418774254. [CrossRef] [PubMed]

47. Li, Z.; Potts-Kant, E.N.; Garantziotis, S.; Foster, W.M.; Hollingsworth, J.W. Hyaluronan signaling during ozone-induced lung injury requires TLR4, MyD88, and TIRAP. PLoS ONE 2011, 6, e27137. [CrossRef]

48. Tang, S.-C.; Yeh, S.-J.; Tsai, L.-K.; Hu, C.-J.; Lien, L.-M.; Peng, G.-S.; Yang, W.-S.; Chiou, H.-Y.; Jeng, J.-S. Association between plasma levels of hyaluronic acid and functional outcome in acute stroke patients. J. Neuroinflam. 2014, 11, 101. [CrossRef] 
49. Al'Qteishat, A.; Gaffney, J.; Krupinski, J.; Rubio, F.; West, D.; Kumar, S.; Kumar, P.; Mitsios, N.; Slevin, M. Changes in hyaluronan production and metabolism following ischaemic stroke in man. Brain A J. Neurol. 2006, 129, 2158-2176. [CrossRef] [PubMed]

50. Al Qteishat, A.; Gaffney, J.J.; Krupinski, J.; Slevin, M. Hyaluronan expression following middle cerebral artery occlusion in the rat. Neuroreport 2006, 17, 1111-1114. [CrossRef] [PubMed]

51. Katarzyna Greda, A.; Nowicka, D. Hyaluronidase inhibition accelerates functional recovery from stroke in the mouse brain. J. Neurochem. 2021, 157, 781-801. [CrossRef] [PubMed]

52. Manrique-Castano, D.; Dzyubenko, E.; Borbor, M.; Vasileiadou, P.; Kleinschnitz, C.; Roll, L.; Faissner, A.; Hermann, D.M. Tenascin-C preserves microglia surveillance and restricts leukocyte and, more specifically, $\mathrm{T}$ cell infiltration of the ischemic brain. Brain Behav. Immun. 2021, 91, 639-648. [CrossRef]

53. Shiba, M.; Suzuki, H. Lessons from tenascin-C knockout mice and potential clinical application to subarachnoid hemorrhage. Neural. Regen. Res. 2019, 14, 262-264. [CrossRef] [PubMed]

54. Chelluboina, B.; Chokkalla, A.K.; Mehta, S.L.; Bathula, S.; Dempsey, R.J.; Vemuganti, R. Abstract P776: Post-Stroke Tenascin-C Induction Mediates the Ischemic Pathogenesis. Stroke 2021, 52, AP776. [CrossRef]

55. Zang, N.; Lin, Z.; Huang, K.; Pan, Y.; Wu, Y.; Wu, Y.; Wang, S.; Wang, D.; Ji, Z.; Pan, S. Biomarkers of Unfavorable Outcome in Acute Ischemic Stroke Patients with Successful Recanalization by Endovascular Thrombectomy. Cerebrovasc. Dis. 2020, 49, 583-592. [CrossRef]

56. Lee, S.C.; Liu, W.; Dickson, D.W.; Brosnan, C.F.; Berman, J.W. Cytokine production by human fetal microglia and astrocytes. Differential induction by lipopolysaccharide and IL-1 beta. J. Immunol. 1993, 150, 2659-2667.

57. Tuttolomondo, A.; Pecoraro, R.; Pinto, A. Studies of selective TNF inhibitors in the treatment of brain injury from stroke and trauma: A review of the evidence to date. Drug Des. Devel. 2014, 8, 2221-2238. [CrossRef] [PubMed]

58. Sobowale, O.A.; Parry-Jones, A.R.; Smith, C.J.; Tyrrell, P.J.; Rothwell, N.J.; Allan, S.M. Interleukin-1 in Stroke: From Bench to Bedside. Stroke 2016, 47, 2160-2167. [CrossRef]

59. Hotter, B.; Hoffmann, S.; Ulm, L.; Meisel, C.; Fiebach, J.B.; Meisel, A. IL-6 Plasma Levels Correlate With Cerebral Perfusion Deficits and Infarct Sizes in Stroke Patients Without Associated Infections. Front. Neurol. 2019, 10, 83. [CrossRef]

60. Suzuki, S.; Tanaka, K.; Suzuki, N. Ambivalent Aspects of Interleukin-6 in Cerebral Ischemia: Inflammatory versus Neurotrophic Aspects. J. Cereb. Blood Flow Metab. 2009, 29, 464-479. [CrossRef]

61. Losy, J.; Zaremba, J. Monocyte chemoattractant protein-1 is increased in the cerebrospinal fluid of patients with ischemic stroke. Stroke 2001, 32, 2695-2696. [CrossRef] [PubMed]

62. Yamagami, S.; Tamura, M.; Hayashi, M.; Endo, N.; Tanabe, H.; Katsuura, Y.; Komoriya, K. Differential production of MCP-1 and cytokine-induced neutrophil chemoattractant in the ischemic brain after transient focal ischemia in rats. J. Leukoc. Biol. 1999, 65, 744-749. [CrossRef] [PubMed]

63. Verslegers, M.; Lemmens, K.; Van Hove, I.; Moons, L. Matrix metalloproteinase-2 and -9 as promising benefactors in development, plasticity and repair of the nervous system. Prog. Neurobiol. 2013, 105, 60-78. [CrossRef]

64. Zaremba, J.; Ilkowski, J.; Losy, J. Serial measurements of levels of the chemokines CCL2, CCL3 and CCL5 in serum of patients with acute ischaemic stroke. Folia Neuropathol. 2006, 44, 282-289. [PubMed]

65. Muhammad, S.; Planz, O.; Schwaninger, M. Increased Plasma Matrix Metalloproteinase-9 Levels Contribute to Intracerebral Hemorrhage during Thrombolysis after Concomitant Stroke and Influenza Infection. Cerebrovasc. Dis. Extra 2016, 6, 50-59. [CrossRef]

66. Hughes, P.M.; Allegrini, P.R.; Rudin, M.; Perry, V.H.; Mir, A.K.; Wiessner, C. Monocyte chemoattractant protein-1 deficiency is protective in a murine stroke model. J. Cereb. Blood Flow Metab. 2002, 22, 308-317. [CrossRef]

67. Schilling, M.; Strecker, J.K.; Ringelstein, E.B.; Schabitz, W.R.; Kiefer, R. The role of CC chemokine receptor 2 on microglia activation and blood-borne cell recruitment after transient focal cerebral ischemia in mice. Brain. Res. 2009, 1289, 79-84. [CrossRef]

68. Kim, J.S.; Gautam, S.C.; Chopp, M.; Zaloga, C.; Jones, M.L.; Ward, P.A.; Welch, K.M. Expression of monocyte chemoattractant protein-1 and macrophage inflammatory protein-1 after focal cerebral ischemia in the rat. J. Neuroimmunol. 1995, 56, 127-134. [CrossRef]

69. Domac, F.M.; Misirli, H. The role of neutrophils and interleukin-8 in acute ischemic stroke. Neuroscience 2008, 13, $136-141$.

70. Villa, P.; Triulzi, S.; Cavalieri, B.; Di Bitondo, R.; Bertini, R.; Barbera, S.; Bigini, P.; Mennini, T.; Gelosa, P.; Tremoli, E.; et al. The interleukin-8 (IL-8/CXCL8) receptor inhibitor reparixin improves neurological deficits and reduces long-term inflammation in permanent and transient cerebral ischemia in rats. Mol. Med. 2007, 13, 125-133. [CrossRef]

71. Okada, Y.; Copeland, B.R.; Mori, E.; Tung, M.M.; Thomas, W.S.; del Zoppo, G.J. P-selectin and intercellular adhesion molecule-1 expression after focal brain ischemia and reperfusion. Stroke 1994, 25, 202-211. [CrossRef]

72. Zhang, R.; Chopp, M.; Zhang, Z.; Jiang, N.; Powers, C. The expression of P- and E-selectins in three models of middle cerebral artery occlusion. Brain Res. 1998, 785, 207-214. [CrossRef]

73. Edwards, D.N.; Bix, G.J. The Inflammatory Response After Ischemic Stroke: Targeting $\beta 2$ and $\beta 1$ Integrins. Front. Neurosci. 2019, 13, 540. [CrossRef]

74. Borovikova, L.V.; Ivanova, S.; Zhang, M.; Yang, H.; Botchkina, G.I.; Watkins, L.R.; Wang, H.; Abumrad, N.; Eaton, J.W.; Tracey, K.J. Vagus nerve stimulation attenuates the systemic inflammatory response to endotoxin. Nature 2000, 405, 458-462. [CrossRef] 
75. Prass, K.; Meisel, C.; Höflich, C.; Braun, J.; Halle, E.; Wolf, T.; Ruscher, K.; Victorov, I.V.; Priller, J.; Dirnagl, U.; et al. Stroke-induced Immunodeficiency Promotes Spontaneous Bacterial Infections and Is Mediated by Sympathetic Activation Reversal by Poststroke T Helper Cell Type 1-like Immunostimulation. J. Exp. Med. 2003, 198, 725-736. [CrossRef] [PubMed]

76. Rosas-Ballina, M.; Olofsson, P.S.; Ochani, M.; Valdes-Ferrer, S.I.; Levine, Y.A.; Reardon, C.; Tusche, M.W.; Pavlov, V.A.; Andersson, U.; Chavan, S.; et al. Acetylcholine-synthesizing T cells relay neural signals in a vagus nerve circuit. Science 2011, 334, 98-101. [CrossRef]

77. Pavlov, V.A.; Ochani, M.; Yang, L.H.; Gallowitsch-Puerta, M.; Ochani, K.; Lin, X.; Levi, J.; Parrish, W.R.; Rosas-Ballina, M.; Czura, C.J.; et al. Selective alpha7-nicotinic acetylcholine receptor agonist GTS-21 improves survival in murine endotoxemia and severe sepsis. Crit. Care Med. 2007, 35, 1139-1144. [CrossRef] [PubMed]

78. Wang, H.; Yu, M.; Ochani, M.; Amella, C.A.; Tanovic, M.; Susarla, S.; Li, J.H.; Wang, H.; Yang, H.; Ulloa, L.; et al. Nicotinic acetylcholine receptor alpha7 subunit is an essential regulator of inflammation. Nature 2003, 421, 384-388. [CrossRef] [PubMed]

79. Ay, I.; Sorensen, A.G.; Ay, H. Vagus nerve stimulation reduces infarct size in rat focal cerebral ischemia: An unlikely role for cerebral blood flow. Brain Res. 2011, 1392, 110-115. [CrossRef]

80. Wong, C.H.; Jenne, C.N.; Lee, W.Y.; Leger, C.; Kubes, P. Functional innervation of hepatic iNKT cells is immunosuppressive following stroke. Science 2011, 334, 101-105. [CrossRef]

81. Ajmo, C.T., Jr.; Collier, L.A.; Leonardo, C.C.; Hall, A.A.; Green, S.M.; Womble, T.A.; Cuevas, J.; Willing, A.E.; Pennypacker, K.R. Blockade of adrenoreceptors inhibits the splenic response to stroke. Exp. Neurol. 2009, 218, 47-55. [CrossRef]

82. Rupalla, K.; Allegrini, P.R.; Sauer, D.; Wiessner, C. Time course of microglia activation and apoptosis in various brain regions after permanent focal cerebral ischemia in mice. Acta Neuropathol. 1998, 96, 172-178. [CrossRef]

83. Schilling, M.; Besselmann, M.; Leonhard, C.; Mueller, M.; Ringelstein, E.B.; Kiefer, R. Microglial activation precedes and predominates over macrophage infiltration in transient focal cerebral ischemia: A study in green fluorescent protein transgenic bone marrow chimeric mice. Exp. Neurol. 2003, 183, 25-33. [CrossRef]

84. Morrison, H.W.; Filosa, J.A. A quantitative spatiotemporal analysis of microglia morphology during ischemic stroke and reperfusion. J. Neuroinflamm. 2013, 10, 4. [CrossRef] [PubMed]

85. Iadecola, C.; Buckwalter, M.S.; Anrather, J. Immune responses to stroke: Mechanisms, modulation, and therapeutic potential. J. Clin. Investig. 2020, 130, 2777-2788. [CrossRef] [PubMed]

86. Planas, A.M. Role of Immune Cells Migrating to the Ischemic Brain. Stroke 2018, 49, 2261-2267. [CrossRef]

87. Iadecola, C.; Anrather, J. The immunology of stroke: From mechanisms to translation. Nat. Med. 2011, 17, 796-808. [CrossRef]

88. Schilling, M.; Besselmann, M.; Muller, M.; Strecker, J.K.; Ringelstein, E.B.; Kiefer, R. Predominant phagocytic activity of resident microglia over hematogenous macrophages following transient focal cerebral ischemia: An investigation using green fluorescent protein transgenic bone marrow chimeric mice. Exp. Neurol. 2005, 196, 290-297. [CrossRef] [PubMed]

89. Jin, R.; Yang, G.; Li, G. Inflammatory mechanisms in ischemic stroke: Role of inflammatory cells. J. Leukoc. Biol. 2010, 87, 779-789. [CrossRef] [PubMed]

90. Connolly, E.S., Jr.; Winfree, C.J.; Prestigiacomo, C.J.; Kim, S.C.; Choudhri, T.F.; Hoh, B.L.; Naka, Y.; Solomon, R.A.; Pinsky, D.J. Exacerbation of cerebral injury in mice that express the P-selectin gene: Identification of P-selectin blockade as a new target for the treatment of stroke. Circ. Res. 1997, 81, 304-310. [CrossRef] [PubMed]

91. Connolly, E.S., Jr.; Winfree, C.J.; Springer, T.A.; Naka, Y.; Liao, H.; Yan, S.D.; Stern, D.M.; Solomon, R.A.; Gutierrez-Ramos, J.C.; Pinsky, D.J. Cerebral protection in homozygous null ICAM-1 mice after middle cerebral artery occlusion. Role of neutrophil adhesion in the pathogenesis of stroke. J. Clin. Investig. 1996, 97, 209-216. [CrossRef] [PubMed]

92. Shiga, Y.; Onodera, H.; Kogure, K.; Yamasaki, Y.; Yashima, Y.; Syozuhara, H.; Sendo, F. Neutrophil as a mediator of ischemic edema formation in the brain. Neurosci. Lett. 1991, 125, 110-112. [CrossRef]

93. Felger, J.C.; Abe, T.; Kaunzner, U.W.; Gottfried-Blackmore, A.; Gal-Toth, J.; McEwen, B.S.; Iadecola, C.; Bulloch, K. Brain dendritic cells in ischemic stroke: Time course, activation state, and origin. Brain Behav. Immun. 2010, 24, 724-737. [CrossRef]

94. Brait, V.H.; Jackman, K.A.; Walduck, A.K.; Selemidis, S.; Diep, H.; Mast, A.E.; Guida, E.; Broughton, B.R.; Drummond, G.R.; Sobey, C.G. Mechanisms contributing to cerebral infarct size after stroke: Gender, reperfusion, T lymphocytes, and Nox2-derived superoxide. J. Cereb. Blood Flow Metab. 2010, 30, 1306-1317. [CrossRef] [PubMed]

95. Kleinschnitz, C.; Schwab, N.; Kraft, P.; Hagedorn, I.; Dreykluft, A.; Schwarz, T.; Austinat, M.; Nieswandt, B.; Wiendl, H.; Stoll, G. Early detrimental T-cell effects in experimental cerebral ischemia are neither related to adaptive immunity nor thrombus formation. Blood 2010, 115, 3835-3842. [CrossRef] [PubMed]

96. Yilmaz, G.; Arumugam, T.V.; Stokes, K.Y.; Granger, D.N. Role of T lymphocytes and interferon-gamma in ischemic stroke. Circulation 2006, 113, 2105-2112. [CrossRef] [PubMed]

97. Liesz, A.; Zhou, W.; Mracsko, E.; Karcher, S.; Bauer, H.; Schwarting, S.; Sun, L.; Bruder, D.; Stegemann, S.; Cerwenka, A.; et al. Inhibition of lymphocyte trafficking shields the brain against deleterious neuroinflammation after stroke. Brain A J. Neurol. 2011, 134, 704-720. [CrossRef]

98. Ito, M.; Komai, K.; Mise-Omata, S.; Iizuka-Koga, M.; Noguchi, Y.; Kondo, T.; Sakai, R.; Matsuo, K.; Nakayama, T.; Yoshie, O.; et al. Brain regulatory T cells suppress astrogliosis and potentiate neurological recovery. Nature 2019, 565, 246-250. [CrossRef] [PubMed]

99. Clark, R.K.; Lee, E.V.; White, R.F.; Jonak, Z.L.; Feuerstein, G.Z.; Barone, F.C. Reperfusion following focal stroke hastens inflammation and resolution of ischemic injured tissue. Brain Res. Bull. 1994, 35, 387-392. [CrossRef] 
100. Ralph, S.J.; Weissenberger, A.; Bonev, V.; King, L.D.; Bonham, M.D.; Ferguson, S.; Smith, A.D.; Goodman-Jones, A.A.; Espinet, A.J. Phase I/II parallel double-blind randomized controlled clinical trial of perispinal etanercept for chronic stroke: Improved mobility and pain alleviation. Expert Opin. Investig. Drugs 2020, 29, 311-326. [CrossRef]

101. Wu, M.-H.; Huang, C.-C.; Chio, C.-C.; Tsai, K.-J.; Chang, C.-P.; Lin, N.-K.; Lin, M.-T. Inhibition of Peripheral TNF- $\alpha$ and Downregulation of Microglial Activation by Alpha-Lipoic Acid and Etanercept Protect Rat Brain Against Ischemic Stroke. Mol. Neurobiol. 2016, 53, 4961-4971. [CrossRef]

102. Yamashita, T.; Sawamoto, K.; Suzuki, S.; Suzuki, N.; Adachi, K.; Kawase, T.; Mihara, M.; Ohsugi, Y.; Abe, K.; Okano, H. Blockade of interleukin-6 signaling aggravates ischemic cerebral damage in mice: Possible involvement of Stat3 activation in the protection of neurons. J. Neurochem. 2005, 94, 459-468. [CrossRef]

103. Wang, S.; Zhou, J.; Kang, W.; Dong, Z.; Wang, H. Tocilizumab inhibits neuronal cell apoptosis and activates STAT3 in cerebral infarction rat model. Bosn. J. Basic. Med. Sci. 2016, 16, 145-150. [CrossRef] [PubMed]

104. Hudobenko, J.; Chauhan, A.; McCullough, L. Abstract 128: Amelioration of Ischemic Stroke Damage Through Inhibition of Interleukin-6 Signaling With Tocilizumab Requires Sex Specific Dosing. Stroke 2019, 50, A128. [CrossRef]

105. Huang, J.; Choudhri, T.F.; Winfree, C.J.; McTaggart, R.A.; Kiss, S.; Mocco, J.; Kim, L.J.; Protopsaltis, T.S.; Zhang, Y.; Pinsky, D.J.; et al. Postischemic cerebrovascular E-selectin expression mediates tissue injury in murine stroke. Stroke 2000, 31, 3047-3053. [CrossRef] [PubMed]

106. Suzuki, H.; Abe, K.; Tojo, S.J.; Kitagawa, H.; Kimura, K.; Mizugaki, M.; Itoyama, Y. Reduction of ischemic brain injury by anti-P-selectin monoclonal antibody after permanent middle cerebral artery occlusion in rat. Neurol. Res. 1999, 21, 269-276. [CrossRef] [PubMed]

107. Veltkamp, R.; Gill, D. Clinical Trials of Immunomodulation in Ischemic Stroke. Neurother. J. Am. Soc. Exp. Neurother. 2016, 13, 791-800. [CrossRef] [PubMed]

108. Enlimomab Acute Stroke Trial Investigators. Use of anti-ICAM-1 therapy in ischemic stroke: Results of the Enlimomab Acute Stroke Trial. Neurology 2001, 57, 1428-1434. [CrossRef]

109. Streit, W.J.; Hurley, S.D.; McGraw, T.S.; Semple-Rowland, S.L. Comparative evaluation of cytokine profiles and reactive gliosis supports a critical role for interleukin-6 in neuron-glia signaling during regeneration. J. Neurosci. Res. 2000, 61, 10-20. [CrossRef]

110. Lu, Y.; Wahl, L.M. Production of matrix metalloproteinase-9 by activated human monocytes involves a phosphatidylinositol-3 kinase/Akt/IKKalpha/NF-kappaB pathway. J. Leukoc. Biol. 2005, 78, 259-265. [CrossRef]

111. Moldovan, L.; Moldovan, N.I. Role of monocytes and macrophages in angiogenesis. EXS 2005, 127-146.

112. Scharfman, H.; Goodman, J.; Macleod, A.; Phani, S.; Antonelli, C.; Croll, S. Increased neurogenesis and the ectopic granule cells after intrahippocampal BDNF infusion in adult rats. Exp. Neurol. 2005, 192, 348-356. [CrossRef] [PubMed]

113. Unoki, N.; Murakami, T.; Nishijima, K.; Ogino, K.; van Rooijen, N.; Yoshimura, N. SDF-1/CXCR4 contributes to the activation of tip cells and microglia in retinal angiogenesis. Investig. Ophthalmol. Vis. Sci. 2010, 51, 3362-3371. [CrossRef]

114. Yan, Y.P.; Sailor, K.A.; Lang, B.T.; Park, S.W.; Vemuganti, R.; Dempsey, R.J. Monocyte chemoattractant protein-1 plays a critical role in neuroblast migration after focal cerebral ischemia. J. Cereb. Blood Flow Metab. 2007, 27, 1213-1224. [CrossRef]

115. Kodama, H.; Inoue, T.; Watanabe, R.; Yasutomi, D.; Kawakami, Y.; Ogawa, S.; Mikoshiba, K.; Ikeda, Y.; Kuwana, M. Neurogenic potential of progenitors derived from human circulating CD14+ monocytes. Immunol. Cell Biol. 2006, 84, 209-217. [CrossRef]

116. Lalive, P.H.; Paglinawan, R.; Biollaz, G.; Kappos, E.A.; Leone, D.P.; Malipiero, U.; Relvas, J.B.; Moransard, M.; Suter, T.; Fontana, A. TGF-beta-treated microglia induce oligodendrocyte precursor cell chemotaxis through the HGF-c-Met pathway. Eur. J. Immunol. 2005, 35, 727-737. [CrossRef] [PubMed]

117. Mitrovic, B.; Ignarro, L.J.; Vinters, H.V.; Akers, M.A.; Schmid, I.; Uittenbogaart, C.; Merrill, J.E. Nitric oxide induces necrotic but not apoptotic cell death in oligodendrocytes. Neuroscience 1995, 65, 531-539. [CrossRef]

118. Liu, X.; Liu, J.; Zhao, S.; Zhang, H.; Cai, W.; Cai, M.; Ji, X.; Leak, R.K.; Gao, Y.; Chen, J.; et al. Interleukin-4 Is Essential for Microglia/Macrophage M2 Polarization and Long-Term Recovery After Cerebral Ischemia. Stroke 2016, 47, 498-504. [CrossRef]

119. Albini, A.; Marchisone, C.; Del Grosso, F.; Benelli, R.; Masiello, L.; Tacchetti, C.; Bono, M.; Ferrantini, M.; Rozera, C.; Truini, M.; et al. Inhibition of angiogenesis and vascular tumor growth by interferon-producing cells: A gene therapy approach. Am. J. Pathol. 2000, 156, 1381-1393. [CrossRef]

120. Facciabene, A.; Peng, X.; Hagemann, I.S.; Balint, K.; Barchetti, A.; Wang, L.P.; Gimotty, P.A.; Gilks, C.B.; Lal, P.; Zhang, L.; et al. Tumour hypoxia promotes tolerance and angiogenesis via CCL28 and T(reg) cells. Nature 2011, 475, 226-230. [CrossRef] [PubMed]

121. Larsson, J.; Goumans, M.J.; Sjostrand, L.J.; van Rooijen, M.A.; Ward, D.; Leveen, P.; Xu, X.; ten Dijke, P.; Mummery, C.L.; Karlsson, S. Abnormal angiogenesis but intact hematopoietic potential in TGF-beta type I receptor-deficient mice. EMBO J. 2001, 20, 1663-1673. [CrossRef] [PubMed]

122. Snyder, J.S. Recalibrating the Relevance of Adult Neurogenesis. Trends Neurosci. 2019, 42, 164-178. [CrossRef] [PubMed]

123. Ming, G.-L.; Song, H. Adult neurogenesis in the mammalian brain: Significant answers and significant questions. Neuron 2011, 70, 687-702. [CrossRef]

124. Naik, S.; Larsen, S.B.; Cowley, C.J.; Fuchs, E. Two to Tango: Dialog between Immunity and Stem Cells in Health and Disease. Cell 2018, 175, 908-920. [CrossRef]

125. Grund-Gröschke, S.; Stockmaier, G.; Aberger, F. Hedgehog/GLI signaling in tumor immunity-new therapeutic opportunities and clinical implications. Cell Commun. Signal. 2019, 17, 172. [CrossRef] 
126. Haseeb, M.; Pirzada, R.H.; Ain, Q.U.; Choi, S. Wnt Signaling in the Regulation of Immune Cell and Cancer Therapeutics. Cells 2019, 8, 1380. [CrossRef] [PubMed]

127. Khosla, R.; Vyas, A.K.; Trehanpati, N. Dichotomy of Notch signalling in regulating tumour immune surveillance. Scand. J. Immunol. 2019, 89, e12744. [CrossRef] [PubMed]

128. Boshuizen, M.C.S.; Steinberg, G.K. Stem Cell-Based Immunomodulation After Stroke: Effects on Brain Repair Processes. Stroke 2018, 49, 1563-1570. [CrossRef]

129. Jin, Y.; Raviv, N.; Barnett, A.; Bambakidis, N.C.; Filichia, E.; Luo, Y. The shh signaling pathway is upregulated in multiple cell types in cortical ischemia and influences the outcome of stroke in an animal model. PLoS ONE 2015, 10, e0124657. [CrossRef]

130. Wei, Z.; Chigurupati, S.; Arumugam, T.V.; Jo, D.G.; Li, H.; Chan, S.L. Notch activation enhances the microglia-mediated inflammatory response associated with focal cerebral ischemia. Stroke 2011, 42, 2589-2594. [CrossRef]

131. Marchetti, B.; Pluchino, S. Wnt your brain be inflamed? Yes, it Wnt! Trends. Mol. Med. 2013, 19, 144-156. [CrossRef] [PubMed]

132. Yang, Y.; Zhang, Z. Microglia and Wnt Pathways: Prospects for Inflammation in Alzheimer's Disease. Front. Aging Neurosci. 2020, 12, 110. [CrossRef]

133. Lengfeld, J.E.; Lutz, S.E.; Smith, J.R.; Diaconu, C.; Scott, C.; Kofman, S.B.; Choi, C.; Walsh, C.M.; Raine, C.S.; Agalliu, I.; et al. Endothelial Wnt/ $\beta$-catenin signaling reduces immune cell infiltration in multiple sclerosis. Proc. Natl. Acad. Sci. USA 2017, 114, E1168-E1177. [CrossRef] [PubMed]

134. Yao, L.; Kan, E.M.; Kaur, C.; Dheen, S.T.; Hao, A.; Lu, J.; Ling, E.-A. Notch-1 signaling regulates microglia activation via NF- $к B$ pathway after hypoxic exposure in vivo and in vitro. PLOS ONE 2013, 8, e78439. [CrossRef]

135. Marei, H.E.; Hasan, A.; Rizzi, R.; Althani, A.; Afifi, N.; Cenciarelli, C.; Caceci, T.; Shuaib, A. Potential of Stem Cell-Based Therapy for Ischemic Stroke. Front. Neurol. 2018, 9, 34. [CrossRef]

136. Thored, P.; Heldmann, U.; Gomes-Leal, W.; Gisler, R.; Darsalia, V.; Taneera, J.; Nygren, J.M.; Jacobsen, S.E.; Ekdahl, C.T.; Kokaia, Z.; et al. Long-term accumulation of microglia with proneurogenic phenotype concomitant with persistent neurogenesis in adult subventricular zone after stroke. Glia 2009, 57, 835-849. [CrossRef]

137. Wang, J.; Xie, L.; Yang, C.; Ren, C.; Zhou, K.; Wang, B.; Zhang, Z.; Wang, Y.; Jin, K.; Yang, G.Y. Activated regulatory T cell regulates neural stem cell proliferation in the subventricular zone of normal and ischemic mouse brain through interleukin 10. Front. Cell Neurosci. 2015, 9, 361. [CrossRef]

138. Nakano-Doi, A.; Nakagomi, T.; Fujikawa, M.; Nakagomi, N.; Kubo, S.; Lu, S.; Yoshikawa, H.; Soma, T.; Taguchi, A.; Matsuyama, T. Bone marrow mononuclear cells promote proliferation of endogenous neural stem cells through vascular niches after cerebral infarction. Stem Cells 2010, 28, 1292-1302. [CrossRef] [PubMed]

139. Borlongan, C.V. Concise Review: Stem Cell Therapy for Stroke Patients: Are We There Yet? Stem Cells Transl. Med. 2019, 8, 983-988. [CrossRef]

140. Shichita, T.; Ito, M.; Yoshimura, A. Post-ischemic inflammation regulates neural damage and protection. Front. Cell Neurosci. 2014, 8, 319. [CrossRef] [PubMed]

141. Tuttolomondo, A.; Di Raimondo, D.; Pecoraro, R.; Casuccio, A.; Di Bona, D.; Aiello, A.; Accardi, G.; Arnao, V.; Clemente, G.; Corte, V.D.; et al. HLA and killer cell immunoglobulin-like receptor (KIRs) genotyping in patients with acute ischemic stroke. J. Neuroinflamm. 2019, 16, 88. [CrossRef]

142. Gong, G.; Xiang, L.; Yuan, L.; Hu, L.; Wu, W.; Cai, L.; Yin, L.; Dong, H. Protective Effect of Glycyrrhizin, a Direct HMGB1 Inhibitor, on Focal Cerebral Ischemia/Reperfusion-Induced Inflammation, Oxidative Stress, and Apoptosis in Rats. PLoS ONE 2014, 9 , e89450. [CrossRef]

143. Shichita, T.; Ito, M.; Morita, R.; Komai, K.; Noguchi, Y.; Ooboshi, H.; Koshida, R.; Takahashi, S.; Kodama, T.; Yoshimura, A. MAFB prevents excess inflammation after ischemic stroke by accelerating clearance of damage signals through MSR1. Nat. Med. 2017, 23, 723-732. [CrossRef] [PubMed]

144. Lampl, Y.; Boaz, M.; Gilad, R.; Lorberboym, M.; Dabby, R.; Rapoport, A.; Anca-Hershkowitz, M.; Sadeh, M. Minocycline treatment in acute stroke: An open-label, evaluator-blinded study. Neurology 2007, 69, 1404-1410. [CrossRef]

145. Padma Srivastava, M.; Bhasin, A.; Bhatia, R.; Garg, A.; Gaikwad, S.; Prasad, K.; Singh, M.; Tripathi, M. Efficacy of minocycline in acute ischemic stroke: A single-blinded, placebo-controlled trial. Neurol. India 2012, 60, 23-28. [CrossRef] [PubMed]

146. Amantea, D. Polarizing the immune system towards neuroprotection in brain ischemia. Neural. Regen. Res. 2016, 11, 81-82. [CrossRef]

147. Wang, J.; Xing, H.; Wan, L.; Jiang, X.; Wang, C.; Wu, Y. Treatment targets for M2 microglia polarization in ischemic stroke. Biomed. Pharmacother. 2018, 105, 518-525. [CrossRef] [PubMed]

148. Zhao, X.P.; Zhao, Y.; Qin, X.Y.; Wan, L.Y.; Fan, X.X. Non-invasive Vagus Nerve Stimulation Protects Against Cerebral Ischemia/Reperfusion Injury and Promotes Microglial M2 Polarization Via Interleukin-17A Inhibition. J. Mol. Neurosci. MN 2019, 67, 217-226. [CrossRef]

149. Wei, Y.; Yemisci, M.; Kim, H.-H.; Yung, L.M.; Shin, H.K.; Hwang, S.-K.; Guo, S.; Qin, T.; Alsharif, N.; Brinkmann, V.; et al. Fingolimod provides long-term protection in rodent models of cerebral ischemia. Ann. Neurol. 2011, 69, 119-129. [CrossRef]

150. Hendrix, S.; Nitsch, R. The role of T helper cells in neuroprotection and regeneration. J. Neuroimmunol. 2007, 184, 100-112. [CrossRef]

151. Gee, J.M.; Kalil, A.; Shea, C.; Becker, K.J. Lymphocytes. Stroke 2007, 38, 783-788. [CrossRef] 
152. Becker, K.J.; Kindrick, D.L.; Lester, M.P.; Shea, C.; Ye, Z.-C. Sensitization to brain antigens after stroke is augmented by lipopolysaccharide. J. Cereb. Blood Flow Metab. 2005, 25, 1634-1644. [CrossRef]

153. Ayer, R.E.; Ostrowski, R.P.; Sugawara, T.; Ma, Q.; Jafarian, N.; Tang, J.; Zhang, J.H. Statin-induced T-lymphocyte modulation and neuroprotection following experimental subarachnoid hemorrhage. Acta Neurochir. Suppl. 2013, 115, 259-266. [CrossRef]

154. Smith, C.J.; Hulme, S.; Vail, A.; Heal, C.; Parry-Jones, A.R.; Scarth, S.; Hopkins, K.; Hoadley, M.; Allan, S.M.; Rothwell, N.J.; et al. SCIL-STROKE (Subcutaneous Interleukin-1 Receptor Antagonist in Ischemic Stroke): A Randomized Controlled Phase 2 Trial. Stroke 2018, 49, 1210-1216. [CrossRef]

155. Chaudhry, S.R.; Guresir, E.; Vatter, H.; Kinfe, T.M.; Dietrich, D.; Lamprecht, A.; Muhammad, S. Aneurysmal subarachnoid hemorrhage lead to systemic upregulation of IL-23/IL-17 inflammatory axis. Cytokine 2017, 97, 96-103. [CrossRef] [PubMed]

156. Gaffen, S.L.; Jain, R.; Garg, A.V.; Cua, D.J. The IL-23-IL-17 immune axis: From mechanisms to therapeutic testing. Nat. Rev. Immunol. 2014, 14, 585-600. [CrossRef]

157. Konoeda, F.; Shichita, T.; Yoshida, H.; Sugiyama, Y.; Muto, G.; Hasegawa, E.; Morita, R.; Suzuki, N.; Yoshimura, A. Therapeutic effect of IL-12/23 and their signaling pathway blockade on brain ischemia model. Biochem. Biophys. Res. Commun. 2010, 402, 500-506. [CrossRef]

158. Chio, C.C.; Lin, J.W.; Chang, M.W.; Wang, C.C.; Kuo, J.R.; Yang, C.Z.; Chang, C.P. Therapeutic evaluation of etanercept in a model of traumatic brain injury. J. Neurochem. 2010, 115, 921-929. [CrossRef] 